\title{
Screening the church: A study of clergy representation in contemporary Afrikaans cinema
}

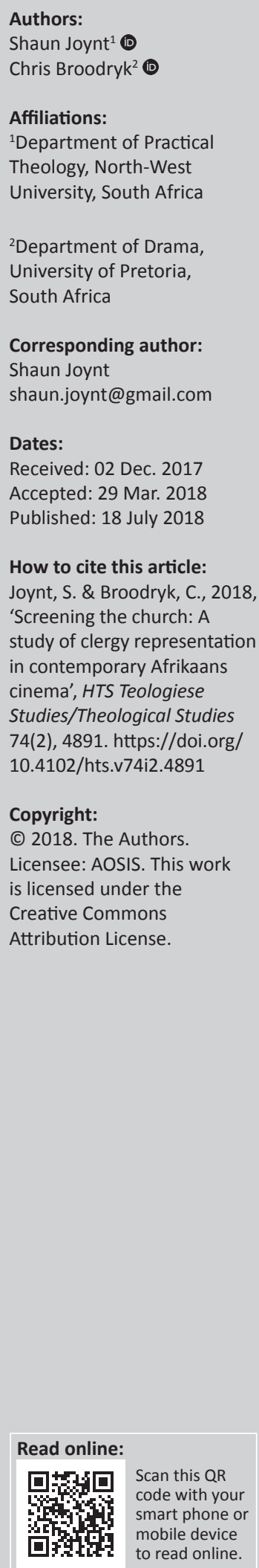

The church-funded CARFO or KARFO (Afrikaans Christian Filmmaking Organisation) was established in 1947, and aimed to '[socialise] the newly urbanized Afrikaner into a Christian urban society' (Tomaselli 1985:25; Paleker 2009:45). This initiative was supported and sustained by the Dutch Reformed Church (DRC), which had itself been part of the sociopolitical and ideological fabric of Afrikaans religious life for a while and would guide Afrikaners through tensions between religious conservatism and liberalism and into apartheid. Given Afrikaans cinema's ties with Christian religious and political conservatism, we explore the role - even the centrality - of the Afrikaans church in cultural activity before 1994, and then after 1994. Here, Afrikaans church is an inclusive term that brings together various denominations of Afrikaans-speaking churches, but which mainly suggests the domination of the DRC. After establishing the role of the Afrikaans church in the way described above, we move towards the primary focus of our study: exploring the representation of clergy in the contemporary Afrikaans film Faan se Trein in order to describe certain theological implications of this representation. With reference to Faan se Trein, our article notes and comments on the shifts that have occurred in clergy representation in Afrikaans cinema over the past decades. Osmer's four tasks of practical theology, namely, descriptive, interpretive, normative and strategic are used for theological reflection. With due contextual reference to Afrikaans film dramas such as Broer Matie [Brother Matie], Saak van Geloof [A Matter of Faith], Roepman [Stargazer], Stilte [Silence], Suiderkruis [Southern Cross] and Faan se Trein, we arrive at some preliminary conclusions about the representation of clergy in mainly contemporary Afrikaans cinema.

\section{Introduction}

Scholars such as Lucia Saks (2011:138) and Jacqueline Maingard (2013:19) have commented on the similarities between American filmmaker DW Griffith's epic, controversial drama The Birth of a Nation and Harold Shaw's triumphant De Voortrekkers [Winning a Continent], both released in 1916, but with Birth of a Nation only distributed in South Africa in the mid-1920s at the earliest. Both films became infamous for offering visually powerful storytelling and for using religion and ideology to infuse their narratives of white exceptionalism. Similar to American cinema, South African cinema has a long film history in which religion and the image serve narratives of spiritual salvation as well as nationalism. Our focus is, however, on more contemporary religious dramas in Afrikaans cinema, where Afrikaans cinema refers to feature films made primarily in the Afrikaans language. Similarly, Afrikaans church here is an inclusive term that brings together various denominations of the Afrikaans-speaking churches, but mainly suggests the domination of the Dutch Reformed Church (DRC). In apartheid South Africa, white public schools and the Afrikaans church (specifically the DRC) were central in sustaining a sociopolitical white Afrikaans hegemony and white Afrikaans cultural salience founded on oppression and privilege (see [Althusser 1976]; also see [Giliomee 2003:489-498]).

The Afrikaans church continues to play a prominent role not only in the social fabric of many Afrikaans-speaking individuals but also in their cultural production, which possibly emanates from and certainly addresses these individuals. Our attention to Faan se Trein [Faan's Train, Roets 2014] occurs against the backdrop of various Afrikaans films that display evangelical interests' narratives centred on characters' faith-based pursuits. Contemporary Afrikaans cinema often evokes clergy in dramatic scenes or to convey some sort of moral of the story. Consider Saak van Geloof [A Matter of Faith, Kempen 2011], in which a young unwed woman claims immaculate conception when she falls pregnant. Her father and mother do their best to come to terms with what is obviously their daughter's personal struggle with an unwanted pregnancy, but the town 
minister (played by Nicky van der Berg) preaches fire and brimstone and treats the young woman with disdain. In Paul Eilers' Roepman [Stargazer, 2011], young Timus (Paul Loots) befriends the messianic Joon (John-Henry Opperman), a railway worker in 1966 Durban whose actions and goodwill culminate in an act of sacrifice. Stilte [Silence, Roodt 2012] offers the point of view of a female protagonist (played by Angelique Pretorius) facing a religious crisis following the murder of her parents. Recovering on her uncle's farm in Oudtshoorn, the mute-by-choice woman hesitantly befriends the local pastor (played by André Frauenstein) who guides her to find her voice again. Whereas Stilte has overt romantic aspirations, the more deliberately evangelical minded Suiderkruis [Southern Cross, Olwage 2015] recounts the tale of four children's childhood and adulthood as they go on a road trip across South Africa, (re)discovering themselves and their faith in the process.

Compared to the above films, Faan se Trein has a certain cultural prestige and box office clout that the other titles mentioned above do not have. Faan se Trein won nine awards at the 2013 Silwerskerm [Silver screen] Film Festival (FilmContact 2014) and the film sold 32000 tickets in its opening weekend (Maroela Media 2014). Moreover, when giving the film his blessing, prominent film critic Leon Van Nierop (2014) described the film as 'proudly Afrikaans'. By the end of 2014, Faan se Trein was the 35th most financially successful film at the competitive South African box office, including local and international releases (CityPress 2014). Focusing primarily but not exclusively on Faan se Trein, we are guided by the following research question: in what ways can Osmer's four tasks of practical theology illuminate contemporary Afrikaans film's representations of clergy?

\section{Christianity and the Church in film: A brief overview}

Early filmmaking in South Africa was indebted to American filmmaking in a number of ways, to the point where pioneering film scholars such as Thelma Gutsche became concerned about American visual culture's grip on the South African (and Afrikaans) cinematic imaginary (Masilela 2000:64). The portrayal of religious figures in film is well documented in Paietta's (2005) work titled Saints, Clergy and Other Religious Figures on Film and Television, 1895-2003 where she notes:

there is little doubt that the media have had a strong influence on how society views religious leaders, and that movies and television have shaped our perception of them. Filmmakers did not create the stereotypes, but movies do embellish society's preexisting feelings. (p. 1)

However, this was not a one-sided affair as Hollywood and the church 'seemed to be mutually reinforcing each other's needs and values' as evidenced by Congregational minister Herbert Jump's comparison, published in 1911, of the religious possibilities of film to Jesus' use of parables (Johnston 2006:43). After the First World War, commercialism, in reaction to 19th-century attitudes, and the rise of the '[actor] star system', changed the motion picture landscape (Johnston 2006:43). From 1923 onwards, Cecile B. DeMille exerted influence through this new medium when he gave the post-First World War public what they wanted - 'a religious gloss over salacious scenes ... and effective combination of debauchery and piety' - and in the process even rewrote the biblical story as seen in his 1927 film The King of Kings (Johnston 2006:44). His continued success using this method of 'sex and piety' eventually led to a confrontation with churches, specifically the Roman Catholic Church, especially after the release of his film, The Sign of the Cross in 1932 (Johnston 2006:45).

By 1930, the Motion Picture Production Code exerted moral influence by requiring immoral behaviour in films to be compensated with uplifting moral lessons (Paietta 2005:1). The code also required treating religious characters with respect, allowing for struggles in their personal dealings yet conveying a message that they dealt with troubles effortlessly (Paietta 2005:1). This moral influence was short lived as the Great Depression saw studios luring back patrons by means of sex and violence (Johnston 2006:46). By the 1960s a new code was developed by the Motion Picture Association of America and the church was excluded - 'sympathy could now be thrown to the side of wrong doing and sin' - and in some films a backlash against the church and clerics ensued (Johnston 2006:49). This turn of events forced the church to 'interact theologically in a new way with Hollywood' because dialogue was required instead of censorship, if the church was still to have an influence in film and television (Johnston 2006:49).

Within the media of film and television, religious figures have been portrayed as 'heroes, villains, mad men, ineffectual buffoons, money grubbers, snobs, humanitarians, drunks, saints, saviors, weak-willed molesters, and murderers' and tend towards being either 'miraculously pure or despicably evil and hypocritical' (Paietta 2005:1; cf Barna Group 2017:114). Research conducted by the Barna Group (2017:114) indicates that the American public has had a more favourable personal real-life experience with clergy (48\%) than what is portrayed in the media, while $39 \%$ said it was the same as what is portrayed in the media. ${ }^{1}$

A search using the parameters (clergy OR pastor OR minister OR priest) AND (movies OR film OR motion picture) AND (South Africa) via EBSCOhost yielded one return which was irrelevant to this article. ${ }^{2}$ Additional searches via AOSIS Publishing, ${ }^{3}$ a national academic journal publishing house located in South Africa, yielded seven results with none pertaining to the research topic of religious figures in South

1.The question 'Has your personal, real-life experience of Christian ministers been more favorable, less favorable, or about the same as how the media portrays pastors, priests, and other ministers?' was asked of a sample of $(n=1025)$ US adults aged 18 years and older.

2.Search was conducted on 18 September 2017 and the following databases were accessed: Academic Search Complete Africa-Wide Information, ATLA Religion accessed: Acth ATLASerials, Audiolet, Aflcaction, Database with ATLASerials, Audiobook Collection, eBook Collection, E-Journals, ERIC, Humanities Source, MasterFILE Premier, Newspaper Source, PsycARTICLES, (2008-2017) and peer-reviewed articles.

3.The search query https://library.aosis.co.za/index.php/misearch/results yielded 11 results for the date range 2008-2017. 
African film. The gap for researching the portrayal of clergy within South African film and television has thus been identified and this article initiates a series of articles on this specific research topic.

\section{Broer Matie and the Church in pre-1994 Afrikaans cinema}

For present purposes, our historical point of reference in this investigation of Afrikaans cinema and the church (clergy) is the late Jans Rautenbach's Broer Matie [Brother Matie], a 1984 drama. Martin Botha (2016) describes the film's plot and context as follows:

With happenings like the Sharpeville massacre still fresh in everyone's mind, the main character causes furore in a rural community when his last will and testament determines that a church minister of colour should conduct the sermon at his funeral. [...] Rautenbach exposes the hypocrisy of white Afrikaners and the importance for this part of the South African community to accept and face a multicultural society in which everyone should be treated as equal.

Not that the film was unequivocally embraced as a landmark film with its liberal sights set on a future of racial harmony within the traditional church structures: Keyan Tomaselli (1989:219) was highly critical of how Broer Matie simplistically 'regurgitated [Rautenbach's] inter-racial theme of the late 1960s'. Tomaselli (2006:37) continues that the film's somewhat propagandistic nature undermines its ostensible political aspirations. ${ }^{4}$ Tomaselli's (2006) concerns were echoed by William Pretorius (1992:384), who additionally found Broer Matie too melodramatic for its own good. Tomaselli (1989:13) is further critical of the film's attempts at 'liberalism': 'the film's message is that "coloureds" should be grateful to whites for including them in the "new dispensation"'. The minister is accepted into the DRC on the condition that he has to 'play white' within the context of the church. In light of Tomaselli and Pretorius' reservations about the film, Broer Matie's overt Christian symbolism may be seen to promote exclusive Western (religious) frameworks as necessary for political as well as religious redemption. Despite the above criticisms, Broer Matie is one of the few overtly political religious dramas of its time and remains a key point of reference for more contemporary cinematic representations of clergy in Afrikaans film.

Ten years before South Africa's transition to democracy, Broer Matie brought the Afrikaans church sharply into cinema's focus. Ten years after 1994, certain Afrikaans films would once again foreground the linkages between the church and Afrikaans identity - but only after Willie Esterhuizen's 1994 comedy Lipstiek Dipstiek [Lipstick Dipstick] featured a crossdressing minister as a supporting character, possibly as a way to defuse the remaining historical tensions around representations of clergymen as righteous figures of divine authority. As the next section will demonstrate, contemporary Afrikaans films that include representations of the church and clergy have opted for somewhat more respectful, even reflective approaches than Esterhuizen's film.

4.Crouch (2011:148) explains that organised religion has historically been a centra mechanism in sustaining state power and control.

\section{The Church in selected Afrikaans films after 1994}

In the vein of Lipstiek Dipstiek, much of Afrikaans cinema between 1994 and 2017 consists of scatological comedies and pleasant social fantasies such as the musical Prêtville and the romantic fairy tale Knysna. Given the narrative and political limitations of these and other contemporary Afrikaans films, we were interested in seeing to what extent DRC clergy representation has remained and even been reconfigured in Faan se Trein.

None of the Afrikaans films discussed in this article include anyone other than white protagonists in their narratives of redemption and salvation. Unlike Broer Matie, the films discussed here for various reasons locate their stories within very specific white Afrikaans-speaking communities. Whereas religion in films such as Broer Matie also performed a political purpose, these films lack any such inclinations.

It is worth noting in genre terms that of the four films referred to in this article, two are period dramas, one is a straightforward religious drama and one is an inspirational romantic drama.

To start with the latter: in the inspirational romantic drama Stilte, a young woman becomes mute following a brutal attack on her family. Recovering on her uncle's farm, she meets a young pastor who guides her towards restoring her faith and finding solace. A problem here is the gendered nature of the story, and whose story gets privileged in the end: hers, or the male pastor's? The woman and the pastor are of similar ages, which immediately opens up the possibility of romance between the characters. The notion of voice becomes important here: the woman is mute, but the pastor speaks. Is the film not in the end primarily about the pastor who fulfils his calling, rather than about the woman's search for meaning? Set in the Oudtshoorn area, Stilte boasts numerous scenic vistas and it climaxes with the young couple releasing lanterns into the sky. The pastor's romantic imperative overshadows his role as spiritual guide, and the film cannot escape the aesthetic conventions (and limitations) of the romantic drama.

Based on Jan van Tonder's novel, the period drama Roepman tells the story of a 1966 railway community told through the eyes of an 11-year-old boy called Timus (Paul Loots). Timus and his family are trapped within the structural violence caused by the government and the church at the time. An unlikely hero, Joon (John-Henry Opperman) often appears to save Timus when he is in trouble. These acts of kindness are seen by Timus as 'miracles' (Korff 2011). The minister's presence in the film is historically appropriate and offers a caring counterpoint to the young boy Timus's abusive experience and the plight of his family. Interestingly, it is Joon who emerges as the messianic figure who most optimally reads as a religious figure and source of divine intervention; he is a far more dynamic presence than the stolid dominee [town minister, religious minister, clergy] character. 
Interestingly, the role of the dominee is played by the film's director, Paul Eilers.

From Stilte, Roepman and Saak van Geloof (discussed earlier) emerges a picture of the dominee as a historical fact, and as cultural residue from a bygone era. The dominees in Saak van Geloof and Roepman are cut from the same cloth, offering selections from scripture that offer little revitalisation to their communities. Both these figures could be seated at the communion table with the ministers and church elders of Broer Matie. Stilte's young pastor seems more invested in how religion can help those in need, but, like Broer Matie, the film is often melodramatic. Imagistically speaking, the lanterns at the end of the film offer a touristic image reminiscent of romanticised spiritual practices in the 'mythic East', which unmoors the film from its South African contexts. The films previously discussed serve as contextual references for our critical reading of the representation of clergy in Faan se Trein. In order to perform this critical reading, we first outline and identify Osmer's four tasks for practical theology in the section below.

\section{Practical theology}

Informally, practical theology is a 'contemplative discipline that has at its heart the desire to enable people to love God more fully and to enjoy God forever' (Swinton \& Mowat 2016) while more formally it is:

the critical, theological reflection on the practices of the Church as they interact with the practices of the world, with the view to ensuring and enabling faithful participation in God's redemptive practices in, to, and for the world. (p. 7)

Although there is no standard way of practicing practical theology and a uniform theology approaching it, there is a good deal of continuity and commonality (Swinton \& Mowat 2016:xi). It is 'shaped by the political, social, cultural, economic, and religious aspects of a specific context' (Dreyer 2012:506) and its roots as an academic discipline in South Africa go back to 1899 (Dreyer 2012:505). It assumes a symbiotic relationship between theory and practice (Poppleton 2017:1). Theological reflection starts with an existing praxis ('a form of action that is value-directed and theory-laden') and 'traverses through critical reflection towards a more faithful form of praxis' (Poppleton 2017:2). Using Osmer's four tasks as set out in this article, we provide a critical reading of Faan se Trein from a specific theological lens, while also demonstrating the use-value of using (this) film in facilitating and informing real-world discussions about the church and its clergy.

\section{Implementing Osmer's four core tasks}

Osmer (2008:4) lists the core tasks of practical theological interpretation after asking four specific questions: What is going on? Why is it going on? What ought to be going on? How might we respond? These questions are similar to the method described by Swinton and Mowat (2016:89-92) that lists four stages, namely the situation, the cultural or contextual analysis, theological reflection and formulating revised forms of practice. Following are Osmer's four tasks used in case study format regarding the film Faan se Trein.

\section{The descriptive-empirical task}

The descriptive-empirical task focuses on 'gathering information that helps us discuss patterns and dynamics in particular episodes, situations or contexts' (Osmer 2008:4). This task requires priestly listening, which is more than just asking questions to obtain information (Osmer 2008:35). Faan se Trein is approached using the descriptive-empirical task that requires priestly listening.

The film (based on two plays written by Pieter Fourie in 1975) is set in 1959. It may be compared to an Afrikaans type of 'Forrest Gump' (Korff 2014) and key themes include ignorance of mental illness, politics and race relations within the community (Nkuna 2014). The story revolves around a simple-minded man, Faan, who lives with his ageing father Frik in a small Karoo town. The town's boys often tease Faan and he struggles to control his anger, lashing out at them and even roughing them up in the process. This results in the town being divided regarding Faan - whether he should be allowed to stay or be committed to a mental institution. Upon his father's death, this communal struggle comes to a climax and the town unites in their efforts to keep Faan in the community.

Of interest to this article is the portrayal of the religious figures or clergy within the film. The Dutch Reformed dominee, an elderly, grey-haired, white man dressed in denominational attire of a black suit, white shirt, white tie and black hat, appears throughout the story. His first appearance ${ }^{5}$ is when he visits one of the oldest community members, Oom [uncle] Frik, after observing that he was absent from the town's prayer day for rain. The dominee is attentive to the plight of the old man who is waiting for news regarding his tender to build the town's new dam using his antiquated equipment and donkeys, as opposed to some of the town council members' desire for the use of new technology, that is, bulldozers. The dominee explains that it is 1959 and that times are changing, but Oom Frik indicates that he lives by his talent and the will of the Lord. The dominee responds by saying sometimes the way of the Lord is not known to man after which Oom Frik requests prayer for his tender of building the dam wall. Then the dominee and Oom Frik walk into the house and catch Faan smoking a cigarette. The dominee greets with 'Good afternoon brother Faan', to which Faan responds with a curt, 'I'm not your brother'. Oom Frik reprimands Faan for speaking disrespectfully to the dominee and Faan replies in anger that he told the dominee that he would bury his own mother, in reference to the coffin he had made for his mother, and yet the dominee elected to bury her in a shop (purchased) coffin. The dominee requests that they move past this incident and Faan says, once again, 5.At 17 m00s-17m52s; $18 \mathrm{~m} 59 \mathrm{~s}-19 \mathrm{~m} 31 \mathrm{~s} ; 19 \mathrm{~m} 50 \mathrm{~s}-21 \mathrm{~m} 25 \mathrm{~s}$ in Faan se Trein (2014). 
that he wanted to bury his mother. Faan then indicates that he will not let that happen again when his father, Frik, passes away. Faan's simple ways are evidenced by statements such as 'Wait until Frik croaks' and 'You won't stuff ol' Frik in a shop coffin'. He threatens to exhume his father's body if they bury him in a shop coffin and Frik tells Faan to stop blaspheming. The dominee changes the conversation by drawing attention to Faan standing idle and smoking. The dominee then quotes scripture stating that the devil finds work for idle hands and Faan retorts that the Bible also states the very same thing - an indication of Faan's ignorance that the dominee was referring to him. Oom Frik then invites the dominee to another room to talk. The dominee tells Oom Frik that Faan attacked one of the town's boys (Gert) after which Oom Frik says it must have been because he was being teased. Then the dominee tells Oom Frik that Faan also assaulted the mayor or doctor's wife. Faan walks in and Oom Frik asks him what he did to Gert and Faan says he strangled him nearly to death. Faan motivates his questionable behaviour: Gert was looking for trouble [teasing him] and he was shooting little birds. The dominee asks for clarity and Oom Frik explains what Faan was referring to [the birds]. Faan then tells the dominee he should kick Gert out of Sunday school and the dominee complies by saying he will do so.

Throughout the film, ${ }^{6}$ the dominee is observed praying with people, quoting scripture, trying to address sensitive issues ${ }^{7}$ (the mayor's wife buying antiques cheaply from impoverished people), listening to disgruntled congregants, ${ }^{8}$ conducting a blessing ceremony ${ }^{9}$ as well as a funeral, ${ }^{10}$ attending to an ill man, 11 admitting to not 'understanding' a portion of scripture $^{12}$ (which was incorrectly exegeted by the person telling this to the dominee), communicating with the simpleminded and mentally challenged Faan, oscillating between his support for Faan remaining in the community or being institutionalised ${ }^{13}$ and marching with the group ${ }^{14}$ (the second march) that requests that Faan be allowed to stay by dropping the charges of assault against him. Visually, the dominee is framed in various shot types from close ups on his face to long shots in which he is shown to be sharing a space with another character. These shots locate the dominee as important to the film narrative and as a servant of the local community.

\section{The interpretive task}

The interpretive task focuses on 'drawing on theories of the arts and sciences to better understand and explain why these 6.From $22 \mathrm{mog} s-22 \mathrm{~m} 47 \mathrm{~s}$ in Faan se Trein (2014).

7.From 30m38s-31m52s in Faan se Trein (2014).

8.From 42m41s-43m31s in Faan se Trein (2014).

9.From $44 \mathrm{~m} 57-45 \mathrm{~m} 17 \mathrm{~s} ; 45 \mathrm{~m} 35 \mathrm{~s}-45 \mathrm{~m} 37 \mathrm{~s} ; 45 \mathrm{~m} 49 \mathrm{~s}-45 \mathrm{~m} 52 \mathrm{~s} ; 46 \mathrm{~m} 16 \mathrm{~s}-46 \mathrm{~m} 21 \mathrm{~s}$; $47 \mathrm{~m} 40 \mathrm{~s}-47 \mathrm{~m} 47 \mathrm{~s} ; 48 \mathrm{m06s}-48 \mathrm{~m} 35 \mathrm{~s}$ in Faan se Trein (2014).

10.From 1h09m34s-1h10m30s in Faan se Trein (2014).

11.From 36m43s-37m40s in Faan se Trein (2014).

12.From 49m00s-49m39s in Faan se Trein (2014).

13.From 1h11m18s-1h12m09s; 1h12m55s-1h13m28s; in Faan se Trein (2014).

14.From 1h38m10s-1h38m45s; 1h38m56s-1h41m07s in Faan se Trein (2014). patterns and dynamics are occurring' (Osmer 2008:4). This task requires sagely wisdom that includes (1) thoughtfulness, (2) theoretical interpretation, and (3) wise judgement (Osmer 2008:82-86). Thoughtfulness is being considerate in the treatment of others and insightful concerning daily life (Osmer 2008:82-83). Theoretical interpretation draws on theories from the arts and sciences to comprehend and respond to the particular contexts (Osmer 2008:83-84). Wise judgement consists of (1) the recognition of the relevant details, (2) the discernment of the moral ends in question and (3) the determination of the most effective means to achieve the moral ends in question - similar to Aristotle's concept of practical wisdom known as phronesis (Osmer 2008:84). Faan se Trein is approached using the interpretive task that requires sagely wisdom.

In Faan se Trein, the dominee is an influential person within the community. He wears a literal hat but also numerous figurative hats indicative of various clergy roles. Clergy roles have been identified, over time, as teacher, pastor, preacher, priest, organiser, administrator (Blizzard 1956:508); counsellor, community problem solver, Christian educationalist, traditionalist (Nelsen, Yokley \& Madron 1973:380); prophet (Reilly 1975); community leader, celebrant of sacraments (Francis \& Rodger 1996:70); equipper, evangelist or disciplemaker (Carroll 2006:119); and fragmented generalist, therapist, CEO and competitor (Pillay 2012:4). One role portrayed by the dominee is that of mediator: speaking up when the mayor's wife buys antiques far below market value and defending Faan's drawings on the church wall while conversing with an angry congregant. Another role is that of peace-maker or peace-keeper: managing conflict between different community members. He wears identifiable clothing - similar to medical or police staff - which contributes to his performance (Miller 2014:188). He is human and makes mistakes, countering 'pedestal placing' by congregants (Reed 2016:308-309). There is also an indication of inadequate training of the dominee when he responds to Oom Frik's identification of the bulldozers as the locusts' iron teeth in reference to Revelation 9:8.

The application of Osmer's interpretive task and in particular the aspect of thoughtfulness, 'being considerate in the treatment of others and insightful concerning daily life' (Osmer 2008:82-83) is displayed in the following ways: (1) when the dominee states to the mayor that Oom Frik has his heart set on building the dam, (2) when he asks the mayor how the town will respond to the him regarding his wife's cheap purchases of their antiques, (3) when he defends Faan's drawings on the side of the church indicating that they are not Satanistic in nature and (4) when he joins with the town folk in marching to deliver antiques to the mayor's wife to secure the release of Faan from prison and prevent Faan from being institutionalised. The dominee uses empathy - placing oneself in another's shoes - to understand the grief situation and mourning needs of others and silence when appropriate (Capretto 2015:343).

Film hermeneutic (Dreyer-Kruger 2017) is considered, in addition to Osmer's theoretical framework, to compliment 
theoretical interpretation. It is the understanding of life and reality by means of 'frames' - this being a result of moving from a typographic culture to a visual culture (Dreyer-Kruger 2017:4). This 'textuality of the screen' (Dreyer-Kruger 2017:8) is a useful tool for public theology and leads to new understandings that attract people existentially (DreyerKruger 2017:9). The use of film in clergy training, both formal and ongoing, is beneficial within a postmodern context of 'the image' as hermeneutic. Faan se Trein offers an opportunity to reflect on the dynamics of human relationships concerning the marginalised within society.

Wise judgement includes identifying the moral ends in question, namely, in this context, the practical living out of the gospel of the kingdom of God as declared by Jesus Christ, in both individual lives and the community as a whole. Concern for the one (Faan) and the many (the community) are dual priorities that need to be managed by clergy. Specific care concerning the rights of the marginalised, in this case the mentally challenged, is the moral responsibility of everyone (World Health Organization 2017). Education, at multiple strata of society, regarding mental health challenges would contribute to improved social cohesion. One such example is Tomorrow's People School (South Africa) that incorporates both healthy and physically and mentally challenged students in the same class, thereby inculcating empathy towards the challenged students within the healthy students and acceptance by healthy students within the challenged students. Faan se Trein analogically highlights the plight of the mentally challenged and demonstrates ways in which clergy can intervene in the community to take greater care of mentally challenged individuals in their midst.

\section{The normative task}

The normative task focuses on 'using theological concepts to interpret particular episodes, situations, or contexts, constructing ethical norms to guide our responses, and learning from "good practice"' (Osmer 2008:4). This task requires prophetic discernment, that is, 'the interplay of divine discourse and human shaping' (Osmer 2008:133-134). Prophetic discernment includes (1) sympathy, (2) theological and ethical interpretation and (3) discernment (Osmer 2008:136-137). Sympathy is 'human participation in God's pathos' (Osmer 2008:136). Theological interpretation is the 'interpretation of present episodes, situations, and contexts with theological concepts' and should include ethical considerations, for example, Niebuhr's Christian moral philosophy that focuses on responsibility (Osmer 2008:139160). He suggests responsibility includes aspects such as (1) acting in response to actions upon oneself, (2) interpreting these actions within larger wholes, (3) being accountable to others for the consequences of one's actions and (4) that these responses are shaped by a community of interpretation with which one identifies (Osmer 2008:140). Discernment is the activity of seeking God's guidance in the midst of everyday life (Osmer 2008:137). Faan se Trein is approached using the normative task that requires prophetic discernment.
Sympathy - feeling compassion for another's hardships as well as participating in God's pathos (Osmer 2008:136) - is displayed when (1) the dominee tries to understand Oom Frik's dream to build the dam in spite of his advanced age and outdated equipment, (2) the dominee defends Faan's innocent childlike drawings on the church wall, (3) the dominee identifies with the people who are financially cheated by the mayor's wife and (4) the dominee oscillates between defending Faan with regards to his drawings on the church wall and the school boys teasing him, and wanting Faan committed to a mental institution when he is accused of 'looking' at girls on the netball courts. Clergy, by nature of their role, sympathise and empathise with 'the other' and need to ensure healthy boundaries to prevent ministry or compassion fatigue (Brunsdon \& Lotter 2011:1). God's compassion, as witnessed in the incarnation of Christ, serves as example for clergy's responses towards their community namely, sympathy and empathy.

Theological interpretation will focus on the dominee's ethical responsibility within a specific situation in the film, namely his interaction with Tante Magriet [Aunt Magriet] regarding Faan's childlike drawing on the church wall. Firstly, Tante Magriet accuses Faan of Satanistic drawings and asks the dominee to act - insinuating that Faan be committed to a mental institution. Secondly, the dominee responds that it is a drawing of a simple-minded person - inferring a moral responsibility to defend the mentally challenged or marginalised. Thirdly, the dominee walks with the town's people to deliver antiques to the mayor's wife in order to secure Faan's release from prison - he cannot defend Faan with words alone as with Tante Magriet, and action is required to substantiate his words. Finally, the whole community accepts Faan as he is and agrees that he needs to stay. Matthew (25:34-40) records Jesus's words concerning feeding the hungry, giving water to the thirsty, accommodating strangers, clothing the naked and visiting prisoners - groups who rely on others with means to meet their needs. This would ring true for the mentally challenged as well.

Discernment is observed when the dominee decides, after being told that Faan has been falsely criminally charged, that he along with others needs to stand for the truth, namely Faan's innocence, and for grace, namely accepting Faan as one of the community. This discernment holds a tension between 'practical' and 'theological'; it is not practiced in a vacuum but within (Morse 2008):

a community shaped by a particular awareness of what is going on in the current situation. This community, or koinonia as denoted in Greek, provides a context for ethical judgments that are not compliant either with a morality prescribed by abstract rules and principles or with an amoral indifference to what is happening. (p. 487)

\section{The pragmatic task}

The pragmatic task focuses on 'determining strategies of action that will influence situations in ways that are desirable and entering into a reflective conversation with the "talk back" 
emerging when they are enacted' (Osmer 2008:4). This task requires servant leadership comprising (1) task competence informed by humility, (2) transformational leadership that leads deep change and (3) transactional leadership that facilitates deep needs and boundary crossing (Osmer 2008:193). Task competence 'takes commitment, hard work, and experience ... [pursued with] humility' and is obtained by acquiring competencies based on the needs of others as well as understanding one's own limitations and need for reliance on others (Osmer 2008:193-194). Transformational leadership leads through the process of change that fundamentally alters identity, culture, operating procedures and mission and it does so by enduring hardships (Osmer 2008:196). Transactional leadership employs persuasion to influence seeking the needs of others above, and different to, one's own needs (Osmer 2008:194-195). Faan se Trein is approached using the pragmatic task that requires servant leadership.

A task competency required by the dominee is to improve his exegetical skills, along with humility, in order to interpret scripture correctly. This would also be an example of servant leadership, as he would serve the congregation by leading them to a better understanding of the scriptures and subsequent application in contemporary matters.

Transformational leaders engage in idealised influence, inspirational motivation, intellection stimulation and individual consideration (Bass \& Avolio 1994:132-135). Transformational leadership is evident within the film. Firstly, the dominee was part of the group that was challenged by the mayor (inspirational motivation and individual consideration) to accept Faan as he was. This would be something the dominee would need to implement and sustain when the mayor had left town. Secondly, some of the community members' intolerance of the mentally challenged changed into acceptance (idealised influence) after the mayor's speech.

The mayor exhibited transactional leadership when he 'traded' all the community's antiques on offer in exchange for Faan's release from prison and proposed committal to a mental institution. By doing so, he increased the participation and compliance of the community (Martínez-Córcolesa \& Stephanou 2017:98) concerning his proposal that Faan should be accepted as he is.

\section{Conclusion}

A case study of clergy representation within Afrikaans cinema was conducted using the film Faan se Trein. Osmer's four tasks of theological reflection provided the practical theological lens. The descriptive-empirical task 'listened' to the dominee; the interpretive task wisely thought, theoretically interpreted and judged the different episodes the dominee found himself in; the normative task discerned what could be learnt from the dominee by means of sympathy and theological or ethical interpretation; and, the pragmatic task considered the servant leadership lessons that could be implemented based on the task competence, transformational leadership and transactional leadership of the dominee.
The representation of clergy in much of contemporary Afrikaans cinema, though problematic, is not without value. We have demonstrated that Faan se Trein in particular provides an opportunity to focus on (contemporary cinematic representations of) clergy role identity, role conflict and task competencies; ethically informed ministry to the marginalised; an appropriate use of empathy and sympathy; transformational, transactional and servant leadership models; and the stereotypical portrayal of clergy in film. The medium of film is not only useful for public theology (Dreyer-Kruger 2017:9-10) but also for clergy development (Baum \& Ortas 1986).

Recommendations for future research include measuring and assessing possible correlations of the depiction of clergy in film with South African audience receptions of these representations, using surveys and questionnaires for data collection purposes and then interpreting this data. Other research recommendations include identifying the representation of clergy across numerous South African social and ethnic groups, thereby presenting a study that has a greater emphasis on representative diversity than the current article; identifying a repository of South African films that would be used for training clergy at seminary and university level and exploring the dialogue between theology and cinema within the South African context beyond the presentation of clergy (for instance, by investigating South African redemption narratives and how such filmic narratives demonstrate the role of religion in facilitating forgiveness, personal agency and political change).

\section{Acknowledgements}

The authors thank Prof. E.M. Lemmer for a critical reading of the first draft and Mrs. T.M. Joynt for editing and proofreading the final copy. A version of this article was presented as a conference paper at the South African Visual Arts Historians annual conference held at the Tshwane University of Technology in Pretoria, South Africa, from 21 to 23 September 2017.

\section{Competing interests}

The authors declare that they have no financial or personal relationships which may have inappropriately influenced them in writing this article.

\section{Authors' contributions}

Both S.J. and C.B. contributed equally to the research and writing of this article.

\section{References}

Althusser, L., 1976, Essays in self-criticism, transl. G. Lock, New Left Books, London.

Barna Group, 2017, The state of pastors: How today's faith leaders are navigating life and leadership in an age of complexity, Barna (www.barna.org), Ventura, CA.

Bass, B.M. \& Avolio, B.J., 1994, Improving organizational effectiveness through transformational leadership, Sage, Thousand Oaks, CA.

Baum, W. \& Ortas, A.M.J., 1986, Guide to the training of future priests concerning the instruments of social communication, viewed 26 November 2017, from http:// www.vatican.va/roman_curia/pontifical_councils/pccs/documents/rc_pc_pccs_ doc_19031986_guide-for-future-priests_en.html 
Blizzard, S., 1956, 'The minister's dilemma', The Christian Century 73, 508-509.

Botha, M.P., 2016, 'The anguish of a dreamer: Abraham (2014) and the cinema of Jans Rautenbach', Kinema: A Journal for Film and Audiovisual Media, viewed 20 Novembe 2017, from http://www.kinema.uwaterloo.ca/article.php?id=590\&feature

Broer Matie, 1984. [Film] Directed by Jans Rautenbach, Satbel Films, South Africa.

Brunsdon, A.R. \& Lotter, G.A., 2011, 'Outo-etnografie as selfhulp vir predikante met bedieningsmoegheid: Verkennende opmerkings', Verbum et Ecclesia 32(1), 1-7. https://doi.org/10.4102/ve.v32i1.465

Capretto, P., 2015, 'Empathy and silence in pastoral care for traumatic grief and loss', Journal Of Religion And Health 54,339-357. https://doi.org/10.1007/s10943014-9904-5

Carroll, J.W., 2006, God's potters: Pastoral leadership and the shaping of congregations, William B. Eerdmans, Grand Rapids, MI.

City Press, 2014, '2014 in review - SA film stumbles at the box office', News24, viewed 20 November 2017, from https://www.news24.com/Archives/City-Press/2014-inreview-SA-film-stumbles-at-the-box-office-20150429

Crouch, C., 2011, The strange non-death of neoliberalism, Polity, Cambridge.

De Voortrekkers, 1916, [Film] Directed by Harold M. Shaw, African Film Productions, South Africa.

Dreyer, J.S., 2012, 'South Africa', in B.J. Miller-McLemore (ed.), The Wiley Blackwell companion to practical theology, pp. 505-524, Wiley-Blackwell, Chichester, UK.

Dreyer-Kruger, A.E., 2017, 'Tekstualiteit van kinematografie: Filmhermeneutiek as publieke teologie', HTS Teologiese Studies/Theological Studies 70(1), 1-11.

Faan se Trein, 2014, [Film] Directed by Koos Roets, Faan Films, South Africa.

FilmContact, 2014, 'Faan se Trein' scores big at box office', FilmContact.com, viewed 19 November 2017, from http://www.filmcontact.com/africa/south-africa/faanse-trein-scores-big-box-office

Francis, L.J. \& Rodger, R., 1996, 'The influence of personality on clergy role prioritisation, role influences, conflict and dissatisfaction with ministry', in L.J. prioritisation, role influences, conflict and dissatisfaction with ministry, in L.J.
Francis \& S.H. Jones (eds.), Psychological perspectives on Christian ministry, pp. Francis \& S.H. Jones (eds.), Psychological perspectives on
$67-77$, Gracewing Publishing, Leominster, Herefordshire.

Giliomee, H.B., 2003, The Afrikaners: Biography of a people, Tafelberg, Cape Town.

Johnston, R.K., 2006, Reel spirituality: Theology and film in dialogue, part 1, 2nd edn., Baker Academic, Grand Rapids, MI.

Korff, J.-M., 2011, 'Roepman', Channel 24, viewed 18 July 2017, from http://www. channel24.co.za/Movies/Reviews/Roepman-20110505

Korff, J.-M., 2014, Faan se Trein, viewed 18 September 2017, from http://www. channel24.co.za/Movies/Reviews/Faan-Se-Trein-20140116

Lipstiek Dipstiek, 1994, [Film] Directed by Willie Esterhuizen, Westel Produksies, South Africa.

Maingard, J., 2013, South African national cinema, Routledge, London.

Maroela Media, 2014, 'Faan se Trein' volstoom in sy eerste naweek by loket, viewed 19 November 2017, from https://maroelamedia.co.za/nuus/sa-nuus/faan-setrein-volstoom-sy-eerste-naweek-loket/

Martínez-Córcolesa, M. \& Stephanou, K., 2017, ‘Linking active transactional leadership and safety performance in military operations', Safety Science 96, 93-101. https:// doi.org/10.1016/j.ssci.2017.03.013

Masilela, N., 2000, 'Thelma Gutsche: A great South African film scholar', Critical Arts: South-North Cultural and Media Studies 14(2), 49-78. https://doi.org/10.1080/ 02560040085310091
Miller, M., 2014, Clothing the clergy: Virtue and power in medieval Europe, c. 800-1200, Cornell University Press, Ithaca, NY.

Morse, C., 2008, 'Paul Lehmann as nurturer of theological discernment', Theology Today 64(4), 484-503. https://doi.org/10.1177/004057360806400406

Nelsen, H.M., Yokley, R.L. \& Madron, T.W., 1973, 'Ministerial roles and social actionist stance: Protestant clergy and protest in the sixties', American Sociological Review 38(3), 375-386. https://doi.org/10.2307/2094360

Nkuna, K., 2014, Movie review: Faan se Trein, viewed 18 September 2017, from https://citizen.co.za/lifestyle/your-life-entertainment-your-life/entertainmentmovies/115724/karoo-classic/

Osmer, R.R., 2008, Practical theology: An introduction, Wm. B. Eerdmans Publishing Co., Grand Rapids, MI.

Paietta, A.C., 2005, Saints, clergy and other religious figures on film and television, 1895-2003, McFarland \& Company Inc. Publishers, Jefferson, NC.

Paleker, G., 2009, Creating a 'black film industry': State intervention and films for African audiences in South Africa, 1956-1990, University of Cape Town, Cape Town.

Pillay, J., 2012, Prestige lecture series: Christian leadership revisited? The role of the pastor in the future of South Africa: What difference can a good pastor make? viewed 06 November 2017, from https://www.ufs.ac.za/docs/librariesprovider19/ all-documents/prestige-lecture-pillay-85-eng.pdf?sfvrsn=0

Poppleton, D., 2017, Augmenting practical theology methods: Creating cultures where transformed and transforming leaders fuel transformational change, viewed 18 September 2017, from https://arl-jrl.org/wp-content/uploads/2017/04/ Poppleton-paper-for-ARL-2017.pdf

Pretorius, W., 1992, 'Afrikaans cinema: Soothing images', Movies, moguls, mavericks: South African cinema 1979-1991, in J. Blignaut \& M. Botha (eds.), pp. 375-394, Showdata, Cape Town.

Reed, A., 2016, 'Rooted in relationship: Longevity in congregational ministry', Review and Expositor 113(3), 303-314. https://doi.org/10.1177/0034637316659304

Reilly, M.E., 1975, 'Perceptions of the priest role', Sociological Analysis 36, 347-356. https://doi.org/10.2307/3710522

Roepman, 2011, [Film] Directed by Paul Eilers, Bosbok Ses Films, South Africa.

Saak van Geloof, 2011, [Film] Directed by Diony Kempen, Aristocept, South Africa.

Saks, L., 2011, 'A tale of two nations: South Africa, "De Voortrekkers" and "Come See the Bioscope"', Ilha do Desterro 61, 137-187. https://doi.org/10.5007/21758026.2011n61p137

Stilte, 2012, [Film] Directed by Darrel James Roodt, Azari Media, South Africa.

Suiderkruis, 2015, [Film] Directed by Willie Olwage, Incense Productions, South Africa.

Swinton, J. \& Mowat, H., 2016, Practical theology and qualitative research, 2nd edn., SCM Press, London, UK.

Tomaselli, K.G., 1985, 'Popular memory and the Voortrekker films', Critical Arts 3(3), 15-24. https://doi.org/10.1080/02560048508559055

Tomaselli, K.G., 1989, The cinema of apartheid, Radix, Sandton.

Tomaselli, K.G., 2006, Encountering modernity: Twentieth century South African cinemas, Rozenberg Publishers, Amsterdam.

Van Nierop, L., 2014, 'Faan se Trein', RSG, viewed 20 November 2017, from http:// www.rsg.co.za/fliekrubriek_meer.asp?id=1917

World Health Organization, 2017, Mental health, human rights \& legislation, viewed 24 November 2017, from http://www.who.int/mental_health/policy/legislation/en/ 